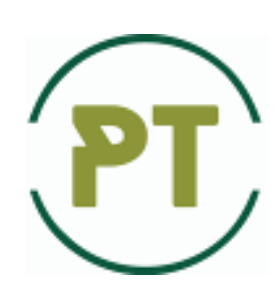

Problems of Tribology, V. 25, No 2/96-2020, 42-48

Problems of Tribology

Website: http://tribology.khnu.km.ua/index.php/ProbTrib

E-mail: tribosenator@gmail.com

DOI: https://doi.org/10.31891/2079-1372-2020-96-2-42-48

\title{
The research on the influence of titanium-tantalum-tungsten-cobalt hard alloy on the tribological properties of phenylone $\mathrm{C}-2$
}

\author{
A.-M.V. Tomina", O.I. Burya, Ye.E. Lytvynova, V.M. Gavrish \\ Dniprovsk State Technical University, Ukraine \\ *E-mail: an.mtomina@gmail.com
}

\begin{abstract}
Polymer composite materials based on aromatic polyamides, filled with dispersed fillers (metal powders, graphite, silicon dioxide and titanium, etc.) are some of the most widely used tribotechnical materials for friction nodes and machinery for automobile and agricultural machinery now. The use of dispersion-hardened polymer composite materials can reduce the cost of manufacturing details at the same time increasing their reliability and working resource. The influence of the content of titanium-tantalum-tungsten-cobalt hard alloy on the tribological properties of composite materials based on phenylone C-2 aromatic polyamide is considered in the article. It has been found that the introduction of titanium-tantalum-tungsten-cobalt hard alloy reduces the intensity of linear wear and abrasion index of phenylone by 35 and 20\%, respectively. It has also been found that the effective content of the filler in the polymer binder is 3 mass.\%. Taking into account all the above, this material can be recommended for the manufacturing of parts of vehicles, road cars and agricultural machines that operate in aggressive conditions, at elevated temperatures, under the influence of abrasive particles and variable loads.
\end{abstract}

Key words: aromatic polyamide, phenylone C-2, hard alloy, carbide, intensity of linear wear, abrasion index, friction coefficient, microhardness

\section{Introduction}

Today, polymer composite materials (PCM) are steadily replacing traditional materials (like steel, cast iron, bronze, babbits, etc.) of structural and tribotechnical purposes. Significant demand for parts made of PCM based on thermoplastic binders is due to their lower shrinkage [1], high resistance to many aggressive factors, long shelf life of prepregs, recyclability [2], environmental friendliness while forming products [3], economy (lower production costs, higher productivity, less weight) [4].

An important role in the stable operation of modern technical devices systems belongs to the friction units [5] that should ensure its effective and long-term life. It is known [6] that in most cases tribounits, which are equipped with serial parts made of metals and alloys, fail in about $90 \%$ of cases due to insufficient wear resistance [7] that causes the equipment to stop functioning. That is why, material scientists are working in order to solve one of the important problems of technical devices: the search for new high-efficiency substitutes for widespread tribotechnical materials.

\section{Literature review}

A perspective way to increase the wear resistance and service life of the friction units of machines and mechanisms completed with metal parts is the use of composites [6], an important place among which dispersion-hardening PCMs take [8]. Thus, PCMs filled with metal powders [5], graphite [7], silicon and titanium dioxide [8] have become widespread.

Taking into account the fact that the polymer matrix is an important component of the composite and guarantees most of its required operating characteristics, it should be carefully chosen. It is known from the literature that the use of thermoplastic binders (polyamide, polyimide, polytetrafluoroethylene, polyether ketone, etc.) is the most promising because it gives an opportunity to get PCMs that can work even in extreme conditions Copyright (๑) 2020 A.-M.V. Tomina, O.I. Burya, Ye.E. Lytvynova, V.M. Gavrish. This is an open access article distributed under the Creative Commons Attribution License, which permits unrestricted use, distribution, and reproduction in any medium, provided the original work is properly cited. 
(elevated temperatures, loads, acids and alkalis). It is advisable to use polyamides to make tribological compounds capable of working in harsh conditions and aggressive environments, if take into account the cost of materials. Due to their high thermal, tribotechnical and physico-mechanical characteristics and relatively low cost, they are of great interest among other thermoplastic binders for the creation of polymer composite materials of tribotechnical purpose.

\section{Purpose}

In view of the above, the purpose of this work was to investigate the effect of titanium-tantalum-tungstencobalt hard alloy on tribotechnical characteristics of phenylone C-2 aromatic polyamide.

\section{Methods}

Aromatic polyamide phenylone C-2 (TU 6-05-221-226-72) was used as a polymer matrix to create PCMs intended for the work of tribounits. PCMs based on phenylone C-2 are characterized by high tribological and physico-mechanical properties that allow their widespread use in tribounits of agricultural, metallurgical and automotive equipment [8]. Thus, the parts made of phenylone are used as tribotechnical material that is operated in a wide range of temperatures. Due to its high strength and hardens, which remain at high temperatures, phenylone is a complete substitute for metals in many cases [9, 10].

The dispersed powder of titanium-tantalum-tungsten-cobalt hard (TTC) alloy (see Fig. 1, made by organization of scientific research of Sevastopol State University) that consists of such main phases as tungsten carbide ( $\mathrm{WC}=83$ mass.\%), titanium ( $\mathrm{TiC}=5$ mass. \%), tantalum $(\mathrm{TaC}=3$ mass.\%) and cobalt binder $(\mathrm{Co}=9$ mass.\%) was used as a filler. The advantages of TTC alloys include high enough hardness, strength and wear resistance.

The preparation of PCMs based on phenylone C-2 aromatic polyamide containing 0.5-5 mass.\% of TTC was carried out by dry mixing in apparatus with a rotating electromagnetic field $(0.12 \mathrm{~T})$ using ferromagnetic particle that were removed from the prepared composition by the method of magnetic separation [6]. The technology of filling in a rotating electromagnetic field, unlike the known method of getting composite materials in a solution of sulfuric acid, allows getting composite with a uniform distribution of the filler in the polymer matrix, while reducing the duration of the process at the same time. Using this method also improves environmental safety compared to the method of getting PCMs in sulfuric acid solution. This is due to the fact that sulfuric acid is one of the aggressive chemicals. The use of it is accompanied by damage to the respiratory tract, skin, mucous membranes, leads to difficulty in breathing, cough, in some cases causes such diseases like laryngitis, tracheitis, bronchitis [6]. That's why sulfuric acid excludes from mixing. Further, the finished mixtures were tableted at room temperature and at a pressure of $25 \mathrm{MPa}$. The prepregs were loaded into the mold heated to $523 \mathrm{~K}$, then it was heated to $598 \mathrm{~K}$ and kept at this temperature for 5 minutes without load and 5 minutes under a load of $40 \mathrm{MPa}[10]$.

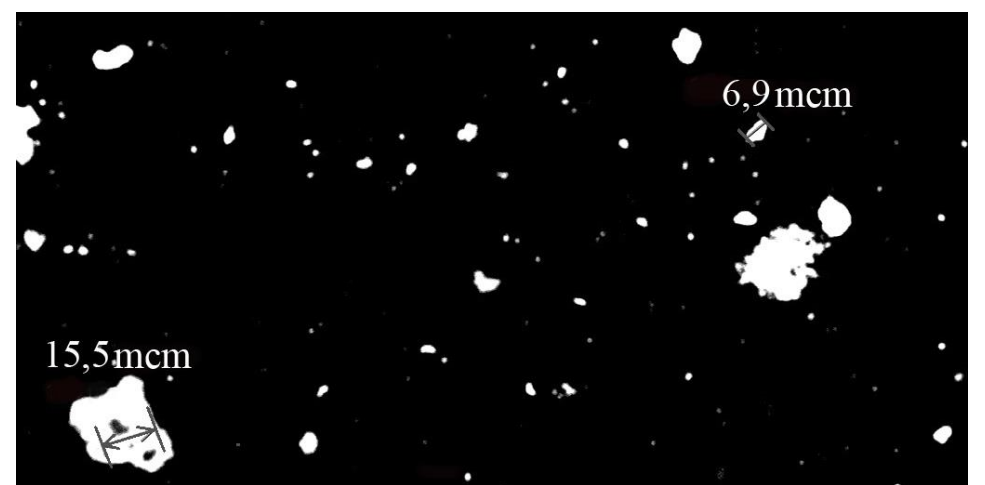

Fig. 1. The size of the particles of titanium-tantalum-tungsten-cobalt hard alloy

Tribotechnical characteristics were studied in the conditions of friction without lubrication on a disk friction machine at a load of $0.6 \mathrm{MPa}$, sliding speed of $1 \mathrm{~m} / \mathrm{s}$ [11]. The friction path was $1000 \mathrm{~m}$. Samples from the compositions were made of cylindrical shape $\varnothing=10, \mathrm{~h}=10 \mathrm{~mm}$; steel 45 (45-48 HRC, Ra=0.16-0.32 mcm) was used as counterbody.

Friction coefficient was calculated by the following formula:

$$
f=\frac{F_{1}+F_{2}}{N},
$$

where $\mathrm{F}_{1}$ is the friction force of the initial sample;

$\mathrm{F}_{2}$ are the losses occurring when the lever is turned on the edges in the horizontal plane. The accuracy of the friction force measurement is 5 ; 
$\mathrm{N}$ is the normal load on the sample.

The wear of the samples was determined by the weight method on the VLR-200 analytical balance (GOST/State Standard 24104-80) with an accuracy of $0.0001 \mathrm{~g}$. The intensity of linear wear $\mathrm{I}_{\mathrm{h}}$ was taken as the main engineering characteristic. It was expressed by the ratio:

$$
I_{h}=\frac{\lambda}{\rho_{T}} \cdot \frac{d G}{A_{a} \cdot d L_{T}}
$$

where $-\lambda=\frac{A_{a}}{A_{T}} ;$

$G$ is the value of mas wear;

$\rho_{T}$ is the density of the material that wears out ;

$A_{a}-$ is the nominal area of contact;

$L$ is the path of friction;

$A_{T}$ is the nominal area of friction.

Accepted $\lambda=1$, that is, the wear of the body, all points of the friction surface of which are in contact, was considered.

The investigation of materials for abrasive wear by fixed abrasive particles (sand cloth dispersion was 40-60 mcm) was carried out according to GOST (State Standard) 11012-69 on a Hecker test machine. The value of abrasion index was determined by the formula:

$$
V_{i}=\frac{\Delta G \cdot 1000}{\rho_{T} \cdot L},
$$

where $\Delta \mathrm{G}$ is the value of mass wear;

$\rho_{\mathrm{T}}$ is the experimental density of the material that wears, $\mathrm{g} / \mathrm{cm}^{3}$;

$\mathrm{L}$ is the length of abrasion path, $\mathrm{m}$.

The density of the samples was determined by calculation and hydrostatic method according to GOST (State Standard) 15139-69. The microhardness of the initial polymer and its composites were determined using a PMT-3M microhardness tester. The morphology of the friction surfaces of the initial polymer and the developed composites based on it were studied using a "NEOPHOT" optical microscope.

\section{Results}

From the results of the studies shown in table 1, it can be seen that the filling of phenylone C-2 with titanium-tantalum-tungsten-cobalt hard alloy leads to a decrease in the intensity of linear wear and abrasion index of the base polymer by $15-35$ and $10-20 \%$, respectively. These results are due to the fact that the particles of the filler weaken the intermolecular bonds of the binder and act as inhibitors of wear of the material, resulting in improvement of tribological properties.

In addition, the decrease in wear of the base polymer can be explained by the fact that titanium-tantalumtungsten-cobalt hard alloy is characterized by high hardness that has a large effect on the increase in wear resistance. Thus. at the introduction of filler from 0.5 to 3 mass. $\%$ the increase in the microhardness of the polymer matrix by $25 \%$ averagely is observed $[11,12]$. As it is known, hardness is nothing but the movement of dislocations. For the initial polymer, their distribution was relatively easy, unlike composites filled with 1-3 mass.\%, because under the influence of external loads carbides create a strong inhibition of dislocations in the binder.

Operational characteristics of phenylone and composites on its base

Table 1.

\begin{tabular}{|c|c|c|c|c|c|}
\hline \multirow{2}{*}{ Index } & \multicolumn{5}{|c|}{ Content of C filler, mass.\% } \\
\cline { 2 - 6 } & 0 & 0,5 & 1 & 3 & 5 \\
\hline Intensity of linear wear, $\mathrm{I}_{\mathrm{h}} \times 10^{-8}$ & 4 & 3,4 & 3 & 2,55 & 2,9 \\
\hline Friction coefficient, $\mathrm{f}$ & 0,52 & 0,53 & 0,55 & 0,58 & 0,56 \\
\hline Abrasive abuse, $V_{i}, \mathrm{~mm}^{3} / \mathrm{m}$ & 1,8 & 1,6 & 1,5 & 1,4 & 1,44 \\
\hline Microhardness, $\mathrm{HV}, \mathrm{MPa}$ & 260 & 278 & 285 & 336 & 291 \\
\hline
\end{tabular}


Regarding the index of the friction coefficient of composites, its increase on average by $12 \%$ is due to the fact that under the conditions of friction without lubrication there is an increase in the adhesive component of friction between the filler and steel counterbody [9]. The solid particles of TTC alloy are characterized by a higher shear resistance than the initial polymer, as a result concentrating on the friction surface of the carbide alloy particles increases the friction forces in the contact zone; the presence of furrows of ploughing on the friction surface can confirm that (see Fig. 2).

The study of the morphology of friction surfaces on the fixed abrasive particles of the initial polymer (see Fig.3, a) showed that the formation of deep furrows on its surface was found; with the introduction of 3 mass. $\%$ of carbide (see Fig.3, b) they decrease, because the appearance of carbides reinforces polymer matrix (that is confirmed by the microhardness data) (Table 1) and inhibits the development of destructive processes (it becomes more difficult for harder particles of abrasive to deform the surface layer of the composite) that reduces abrasion index. Increasing the amount of TTC alloy to 5 mass.\% is accompanied by the removal (loss) of carbide particles from the friction surface of the composite (highlighted by a circle).

The results of tribotechnical characteristics are extreme: the best improvement of these characteristics is observed. when the content of the alloy is 0.5-3 mass. $\%$, they decline with its further increase to 5 mass. $\%$. On the one hand, this can be explained by the fact that as the amount of filler in the polymer matrix increases, the interaction force of the filler particles increases, too.

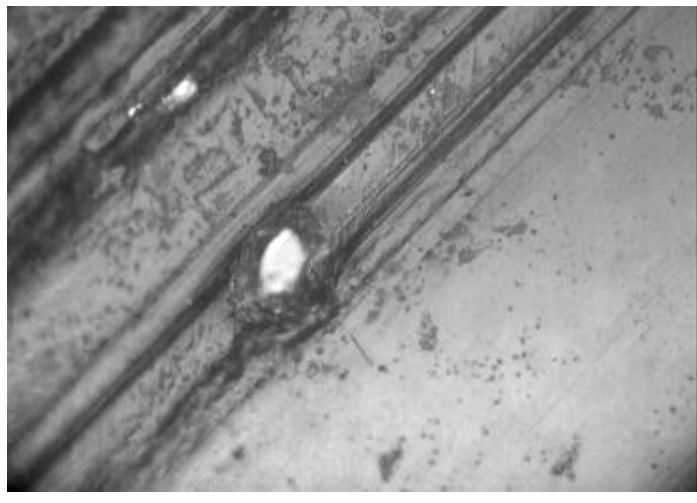

a

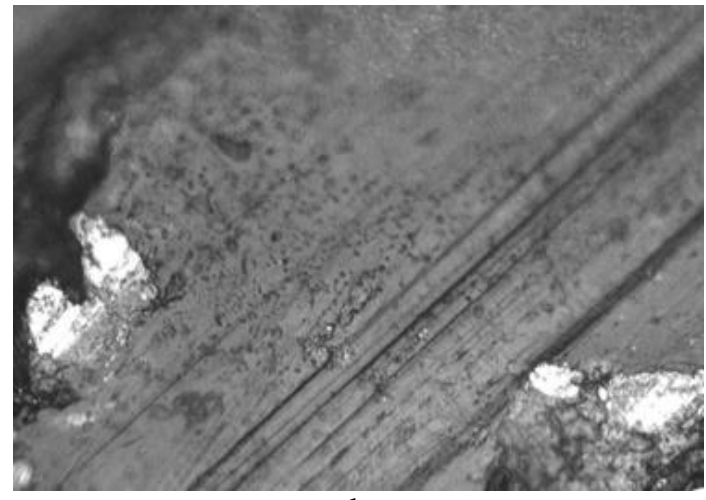

b

Fig. 2. Microstructure of the friction surface of phenylone C-2 filled with 0.5 (a) and 3 (b) mass\% of carbide alloy $(\times 100)$ in the condition of friction without lubrication

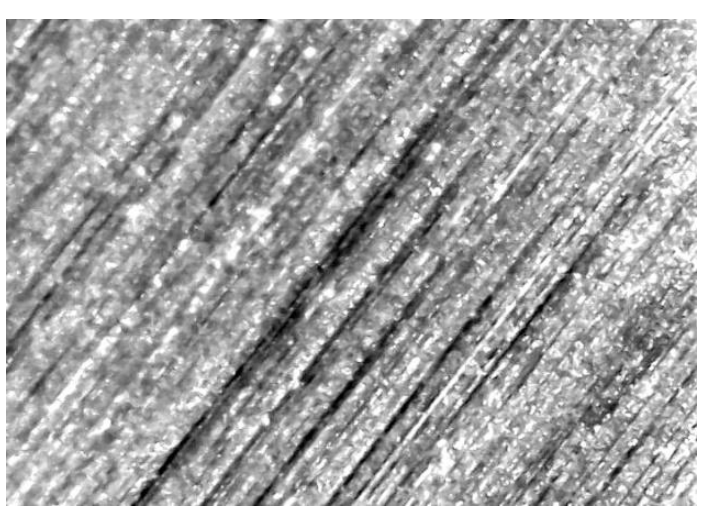

a

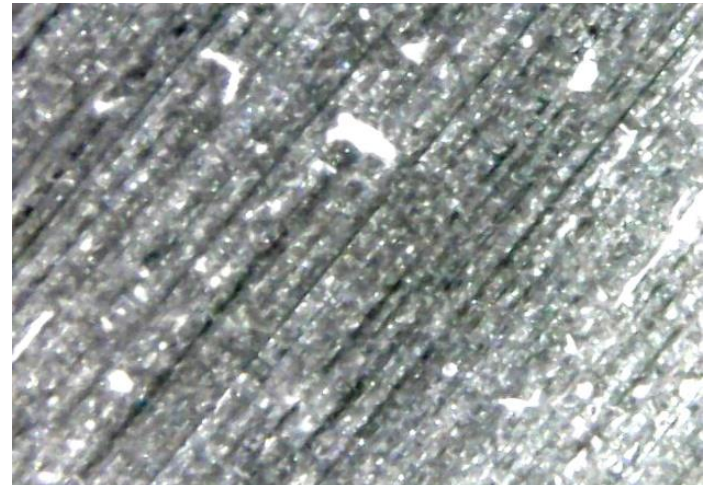

$\mathrm{b}$

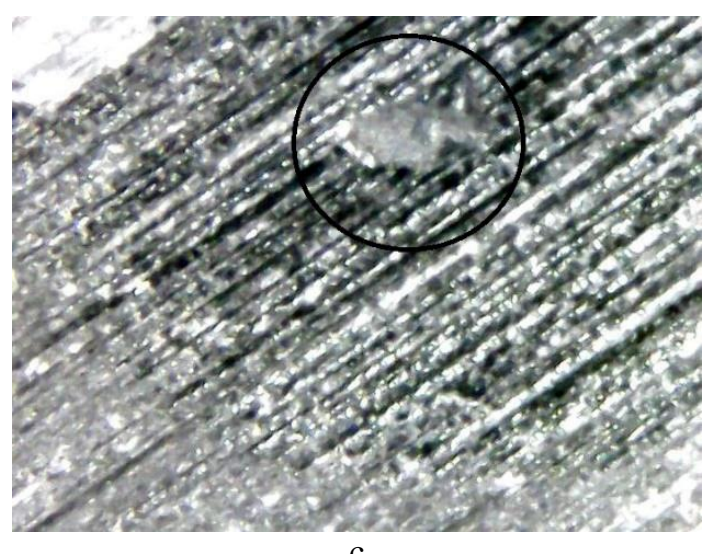

Fig. 3. Morphology of the friction surfaces of phenylone C-2 (a) and filled with 3 (b) and 5 (c) mass.\% of carbide alloy $(\times 100)$ at abrasion 
It is known that carbon in the composition of carbides is characterized by a higher degree of electronegativity (the ability of atoms to attract electrons of other atoms) resulting in the formation of agglomerates that do not allow the polymer to cover titanium-tantalum-tungsten-cobalt alloy evenly; as a result, the particles of the fillers are removed from the friction surface (see Fig.2, b); there is an increase in the surface friction defect of the composite [11].

Density is one of the important sensitive parameters that affect PCMs' operational characteristics. It is known that the chemical interaction between the binder and the filler causes an increase in the concentration of gaseous products in the volume of composites and that leads to the development of processes that affect primarily the density of the material, with help of which it is possible to identify the processes of ordering and softening (the presence of defects in composite volume).

From the data given in Fig. 4 it can be seen that the theoretical density of the developed materials filled with 0.5-3 mass \% of titanium-tantalum-tungsten-cobalt hard alloy is less than the experimental one: the process of binder ordering prevails over the softening at the "binder-carbide alloy" boundary; and only at the content of 5 mass.\% of titanium-tantalum-tungsten-cobalt hard alloy it is higher than experimental (hydrostatic). These studies also confirm the presence of defects (voids, pores) on the "polymer-filler" boundary, when the content of carbide alloy is 5 mass. $\%$.

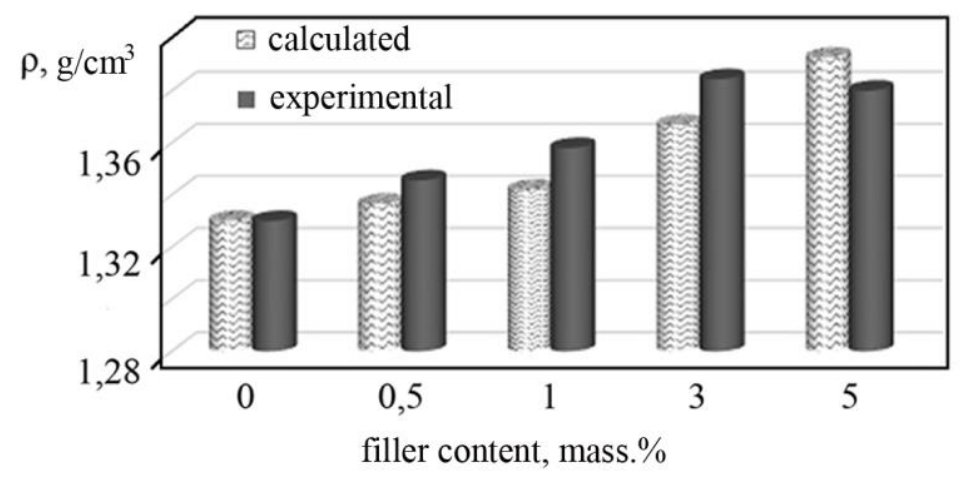

Fig.4. Effect of carbide filler content on the calculated and experimental density of the developed composites

\section{Conclusions.}

Analysis of the results of tribological studies of the developed dispersion-reinforced PCMs has shown that the use of titanium-tantalum-tungsten-cobalt hard alloy as a filler for phenylone $\mathrm{C}$ - 2 aromatic polyamide is a promising way to improve its operational characterisics: reducing the intensity of linear wear and abrasion index, and increasing the microhardness of the polymer matrix by 35, 20 and 25\%, respectively. These results indicate that developed PCMs can be used for the manufacture of durable parts for vehicles, road cars and agricultural machines operating in aggressive conditions, elevated temperatures and variable loads.

\section{References}

1. Sokol`skaya, M.K., Kolosova, A.S., Vitkalov, I.A., Torlova, A.S., \& Pikalov, E.S. (2017). Svyazuyushhie dlya polucheniya sovremenny`kh polimerny`kh kompoziczionny`kh materialov [Binders for the production of modern polymer composite materials]. Fundamental ny`e issledovaniya - Fundamental research. 10, 290-295 [in Russian].

2. Kablov, E.N., Semenova, L.V., Petrova, G.N., \& Perfilova, D.N. (2016). Polimerny`e kompoziczionny`e materialy` na termoplastichnoj matricze [Thermoplastic matrix polymer composites]. Khimiya i khimicheskaya tekhnologiya - Chemistry and chemical technology. 10, 61-71 [in Russian].

3. Bejder, E’.Ya., \& Petrov, G.N. (2015). Termoplastichny`e svyazuyushhie dlya polimerny`kh kompoziczionny`kh materialov [Thermoplastic binders for polymer composite materials]. Trudy` VIAM. Proceedings of VIAM. 11, 40-49 [in Russian].

4. Utevskaya, L.V. (2010). Polimerny`e kompoziczionny`e materialy` konstrukczionnogo naznachenie [Polymeric composite materials for structural purposes]. Visnyk Kharkivskoi derzhavnoi akademii dyzainu i mystetstv - Bulletin of Kharkiv State Academy of Design and Arts. 1, 59-62 [in Russian].

5. Burya, A.I., \& Yeriomina, Ye. A. (2015). The Effect of Various Metallic Filling Materials on the Wear Resistance of Aromatic Polyamide-Based Composite Materials. J. of Friction and Wear. 37, 2, 151-154.

6. Tomina A.-M. . (2019). Vstanovlennia zakonomirnostei vplyvu orhanichnykh volokon na vlastyvosti ta strukturu aromatychnoho poliamidu fenilon [Establishing patterns of influence of organic fibers on the properties and structure of aromatic polyamide phenylone]. Candidate's thesis. Kamianske [in Ukraine]. 
7. Buria, O.I., Yeromina, K.A., Lysenko, O.B., Konchicz, A.A., \& Morozov, A.F. (2019). Polimerni kompozyty na osnovi termoplastychnykh viazhuchykh [Polymer composites based on thermoplastic binders]. Dnipro: Seredniak T.K. [in Ukraine].

8. Kabat, O.S., \& Sy`tar V.I. (2016). Termostojkie kompozity` na osnove fenilona S2 s vy`sokim urovnem tekhnolo-gichnosti pri pererabotki v izdeliya [Heat-resistant composites based on phenylone C2 with a high level of technology during processing into products]. Voprosy` khimii i khimicheskoj tekhnologii. Chemistry and chemical technology issues, Vol.107, 3, 60-64 [in Russian].

9. Ruiz, R., Trigo-López, M., \& García F. (2017). Functional Aromatic Polyamides. J. Polymers. 9, 1-44.

10. Krasnov, A.P., Rashkovan, I.A., \& Afonicheva, O.V. (2006). Trenie i iznashivanie uglerodoplastov na osnove poliamidov razlichnogo khimicheskogo stroeniya [Friction and wear of carbon plastics based on polyamides of various chemical structures]. Trenie i iznos - Friction and wear Trenie i iznos, Vol.27, 5, 527-534.

11. Burya, O.I. Tomina, A.-M.V., \& Lytvynova, Ye.E. (2019). Vplyvu dyspersnoho karbidnoho napovniuvacha na trybolohichni vlastyvosti kompozy-tiv na osnovi fenilonu C-2 [The influence of dispersed carbide filler on tribological properties of composites based on phenylone C-2]. Problemy tertia ta znoshuvannia. - J. Friction and wear problems. 2, 13-18.

12. Okhlopkova, A.A., Petrova, P.N., Popov, S.N., \& Slepczova S.A. (2008). Polimerny`e kompoziczionny`e materialy` tribotekhnicheskogo naznacheniya na osnove politetraftore`tilena [Polymeric composite materials for tribotechnical purposes based on polytetrafluoroethylene]. Rossijskij khimicheskij zhurnal - Russian chemical journal. 3, 147-152. 
Томіна А.-М.В., Буря О.І., , Литвинова Є.Е., Гавріш В.М. Дослідження впливу титано-танталовольфрамо-кобальтового твердого сплаву на трибологічні властивості фенілону С-2

Полімерні композиційні матеріали на основі ароматичних поліамідів, наповнених дисперсними наповнювачами (порошками металів, графітом, діоксидом кремнію та титану тощо) сьогодні $є$ одними 3 розповсюджених матеріалів триботехнічного призначення для вузлів тертя та механізмів авто-мобільної та сільськогосподарської техніки. Використання дисперсно-зміцнених полімерних композиційних матеріалів дозволяє зменшити витрати при виготовленні деталей при одночасному збільшенні їх надійності та робочого ресурсу. У статті розглянуто вплив вмісту титано-тантало-вольфрамокобальтового твердого сплаву на трибологічні властивості композиційних матеріалів на основі ароматичного поліаміду фенілон марки С-2. Встановлено, що введення титано-тантало-вольфрамокобальтового твердого сплаву призводить до зменшення інтенсивності лінійного зношування та показника абразивного стирання фенілону на 35 та 20 \% відповідно. Встановлено, що ефективний вміст наповнювача в полімерному в'яжучому становить 3 мас.\%. Враховуючи зазначене, даний матеріал можна рекомендувати для виготовлення деталей автомобілів, дорожніх та сільськогосподарських машин, які працюють в агресивних умовах, при підвищених температурах, під впливом часток абразиву та змінних навантаженнях.

Ключові слова: ароматичний поліамід, фенілон С-2, твердий сплав, карбід, інтенсивність лінійного зношування, показник абразивного стирання, коефіцієнт тертя, мікротвердість 